\title{
Batubara Malay's Proverbs and Local Working Ethos
}

\author{
Wan Anayati ${ }^{1}$, Bahren Umar Siregar, ${ }^{2}$ Robert Sibarani ${ }^{3}$, T. Thyrhaya Sinar ${ }^{4}$ \\ ${ }_{1,2,3,4}$ Dept. of Linguistics, Postgraduate School, University of Sumatra Utara, Medan (Indonesia)
}

\begin{abstract}
This article studies Batubara Malay's proverbs and their local working ethos. Sixproverbscontaining some values - from advice and motivation to cooperation - constituted samples. The data sources for this study weresamples of proverbs - or sayings - commonly used by local speakers. Islamic Working Ethos (IWE) as proposed by Rokhman (2010) was used to make assessment to the working ethos. Results of the study revealed that based on their forms and meanings the working ethos could be realised by either in literal or non-literal forms and meanings and based on the frequency there were 19 word-list with their distribution range from 10 to 55 tokens. In terms of conceptual mapping, it was found that the ethical values were mapped on human beings, plants, and animals. The working values were mostly in concordance with hard-working with special reference to preservation, enthusiasm, studying hard; with discipline which was related to punctuality; with responsibility within its specific properties of being loyal, honest, sincere, patient, austere, empathetic, and anxious; and with cooperationwithin certain relation to team work, consultation, low profile, support, humble appearance, and righteous doings.
\end{abstract}

Keywords:Proverbs, working ethos, Batubara Malay, responsibility, cooperation.

\section{Introduction}

There were a small number of researches on working ethos in Batubara Malay(BM). BM is a community which is perhaps known to have lower working ethos compared to other nations. The myth "Malays are lazy" was often stigmatized by West to the indigenous Malays in Indonesia in the past although Malay farmers and laborers in various Malay regions showed different conditions with the myth. The "Malays are lazy" hadalso nothing to do with working ethos, but it was more influenced by political and economicalfactors although the economical factor was actually considered as parameter to give values whether a community was prosperous or poor. When this factor became the parameter then--it was hard to deny--the level of prosperity in Malay community was approaching to the real condition of the myth.

Ethics is derived from the Greek word ethos that refers to character, way of life, one's habits, one's motivation or moral purpose and his world view which is reflected in his life. Local valueshould have some teachings on working ethos. Embodiment of working ethos that can be seen from the structure and social norms. The basic nature of the working ethos is founded on behavior and surrounding environment that are dispersed in public life. Cultural value system is formed through a process that takes a very long time. There are five basic problems in human life related to cultural values, namely (i) problem concerning the nature of life, (ii) the nature of the work, (iii) the nature of time, (iv) the nature of nature, and (v) the nature of human relationships. The manifestation of culture of a society is the result of an active response to the environment and this can not be separated from the society itself. The higheror lowerlevels of working ethos of a society depend on how the community members face the cultural values above.

\section{Method}

This study was carried out in Tanjung Tiram sub-district which is administratively under Batubara Regency in North Sumatra Province. This sub-districtwhich is located along the Malay Straits was chosen with a purpose that Malays were the dominant inhabitants here and there was an old village where an old palace Istana Lima Laras which was ever the center of Lima Laras Kingdom is still available. Some local informants were selected for the purpose of this study and for the deep understanding about the proverbs. The informants were in the range of 60 to 70 years of age. The sample comprised five Malay proverbs which were thought to have lost in the Malay people's memories; therefore, some efforts to revitalize such proverbs were done with a hope the new generations would spend time to have direct access to the old proverbs. Tools which were mainly used refer to the information from some local elders who naturally had sufficient knowledge about the proverbs; as a result door-to-door method was applied to assess the perceptions of the elders. Data collection procedures involved the permission taken from the local administration, the distribution of questions to the selected informants, and taking-notes of their opinions. 


\section{Theoretical Reviews}

The majority of BMargued that working was a way to earn a living and gain social status. If a Malay went to work, he or she often said cari makan 'lit. to look for food'. This expression reflectedthe real condition that the BM owned working ethos. Mahathir (2008: internet access) ever said "without having to work harder it was impossible to achieve higher productivity levels. “(1) The lower working ethos among minority of Malays were actually caused by wrong concept of "time". Famous expressions, such as nanti 'later', tunggu 'wait' etc., were dominantly articulated by them. Such expressions, as Mahathir argued, appeared because Malays were trapped in a situation of change which was not adjusted in harmony with the changing attitudes and cultural values. This working ethos was shifted after their land was changed into plantations at the end of the 19th century.BM did not want to be plantation laborersbut farmers and fishermen. On that basis, the Dutch claimed the Malays were lazy. The relationship of language to culture was very close and the analogy of such relationship looked like two sides of a coin. Sibarani (2004:48) argued there were thirteen relationship of language to culture. ${ }^{(2)}$ Although Sinar (2005:41) stressed her opinions that in ancient times Malay nation was the "Conqueror" and "Reigning" other tribes in the archipelago, the today's condition was different: working ethos became the struggle that had be won and gaining that ethos was a big effort. ${ }^{(3)}$ When Islam played a major role in shaping the thinking of Malays, the followers of this religion were hoped to have strong working ethos.

\section{Working Ethos}

The Greek word "ethos"etymologically refers to 'a place to live.'In Webster's Dictionary ethos is defined as (a) guiding belief of a person, institution or groups (ethos is a belief that guides a person, a group or an institution), and (b) fervor earnestness in working, morale with regards to the tasks at hand. This means working ethos is seen as an attitude that leads to an appreciation to work or as efforts to increase productivity. Hornby (1995) defines ethos as the characteristics, spiritual, moral values, ideas of a group, community or culture; characteristic ethos as a spiritual, spirit, moral values, the idea of which is owned by a group, community or culture. Ethos means character, way of life, one's habits, motivation or purpose of one's moral view of the world as well as the description of the way they act or the idea that the most comprehensive about living arrangements . In other words, ethos is the evaluative aspect of the fundamental nature of one self and the world they are reflected in the life (Vault, 2004:8). ${ }^{(4)}$

In the American Herritage Dictionary of English Language, ethosis defined as the disposition of character, attitude peculiar to a specific people, culture, or a group distinguishing it from other people or groups; fundamental value or spirits; mores; ethos is the exposure of character, attitude to life that distinguishes a person or group of people or other groups; more than the underlying value or soul; customs. This is understood that ethos is a set of understanding and confidence in the values that profoundly affect the lives. Ethos and attitude walk in the same manner. Geertz (1973:13) mentioned the nature, working ethos and attitudes which can form the pattern of local culture and primarily exist in religion, symbols, mythology and proverbial phrases, and customs. ${ }^{(5)}$ Gumperz (1982:3) further argued ethos is fundamental attitude toward self and the world. ${ }^{(6)}$ Ethos is evaluative aspect so in this case working ethos is very tied to the rhythm of the character, quality of life, style moral, aesthetic feeling and atmosphere. The concept of ethos in the modern sense was firstdeveloped by the philosopher Immanual Kant (1724-1804) who stated that ethos was autonomous wills and characteristics of every moral. In an online source it was proposed some elements of working ethos, such as, direct responsibility to God, honesty in deeds, hard work, saving, methodically division of the time in everyday life, rational, and responsibility of individuals. ${ }^{(7)}$

Working is culturally meanttogiveafullpositionof honoras wellasamotionof lifethatshouldresult in moreworks(Koentjaraningrat, 1981:192) ${ }^{(8)}$ Usman (1992:12) said to improve working ethos of a person or group of people, they had to take over the cultural values towards the progress and strip the traditional cultural values which were not in accordance with technology which had some characteristics, for instance, accuracy, honesty, rationality, efficiency and time discipline. ${ }^{(9)}$ Kramsch 2001:9) pointed out that there were 14 elements as the "core of modernization", for example, (1) active outlook on life, (2) does not much depend on urban life, (3) the inclination of the orientation of the urban life, (4) individualism, (5) the inclination toward democratic social relations, (6) the need for mass media, (7) equal view of the opportunities ahead in life, (8) do not look down on the field work, (9) do not look down on the job at hand, (10), ensuring quality, (11) give priority to the work, (12) the courage to take risks, (13) orientation to the core of "nuclear family", and (14) low requirement on the activities of religious ceremonies and traditions or customs. ${ }^{(10)}$

The International Encyclopedia of Social Science (1968:283) gavespecific characteristics, such as, (i) the abstract because of the value of a general nature, (ii) contribute to provide a framework in humans to establish norms in society and can influence it, (iii) function in coloring the whole way of life, (iv) is individual (individuality) and adjustment (conformity), (v) is not static and changes in the different values are used in different situations, and (vi) being formed on the base of human and nonhuman sources. The characteristics of the above values can be distinguished by the norm. The values held by a person would form certain attitudes 
within themselves to something (www.academia) ${ }^{(11)}$ This means that value is free and flexible in all situations, while the norm is the guidelines and rules of human behavior that guides way to behave and speak in a circumstance or situation. Norm aims to monitor the behavior of members of the community, clearly defines the shape of a public relations and patterns of behavior that reflects the values of the community. Norms for a society can be replicated and studied by members of the community to facilitate relationships with other community members.Collier (1988:99-120) declared that ethos is a system that regulates the truth of the human person ${ }^{(12)}$ Working ethosreflects the discipline and expects good results, for example, someone who wants a thin body should not consume large amounts of food or someone who wants to earn a lot of money must work.

Swastika (2010:26) argued there are eight good professional working ethos: (1) work is grace, (2) work is a trust, (3) work is call, (4) work is self-actualization, (5) work is worship, (6) work is art, (7) work is honor, and (8) work is service. ${ }^{(13)}$ Swastika (ibid:34)quoted Weber as saying about Germany working ethos: (1) act rationally, (2) disciplined, (3) working hard, (4) oriented material success, (5) frugal and unpretentious, (6) not indulgence in pleasures, and (7) saving and investing. In contrast to the Germans, in the East, the Japanese appreciate the working ethos of the samurai ethos called Bushido. Bushido adheredseven principles, namely: (1) Gi means taking the right decisions based on the truth although it should sacrifice soul because it would make honorable death, (2) Yu means bold and be a gentleman, (3) Jin is generous, loving and to do good to others, (4) $R e$ in the sense of being polite and act properly, (5) Makoto in the sense of being sincere and selfless, (6) Melyo is to maintain the honor, dignity and glory, and (7) in the sense of serving Chugo and royal.

Effendy (2003) suggested that the working ethos of Islam is not merely a rejection of life but rather the fulfillment of life through the concept of ethics based on the Quran and Sunnah. ${ }^{(14)}$ Islam presents the foundations of ideology on the diversity of each individualcontribution in developing economic life. He added that the work ethic of the application in accordance with the history of Islam has brought society to the golden era of Islam in the 8th century until the 14th. Since BMs are Moslems in general, the proverbs might be related to the concept of Islam. Rokhman(2010:6) proposed Islamic Working Ethos (IWE) consisting of nine elements: 1. Laziness is a crime, 2. Dedication to work is a virtue, 3. Good job benefits themselves and others, 4. Justice and generosity in the workplace is a requirement for public health, 5 . Job is not an end but a test of personality and social relationships, 6. Life will not be useful without a job, 7. Hire enables humans to control nature, 8. Job gives a person the opportunity to independent, and 9. Creative work of perfection and happiness. ${ }^{(15)}$ Saidi (1997) said that working ethos is the essence of human life where the work itself is a blessing of God that gives lawful source of income and not immoral. ${ }^{(16)}$ Dewan Bahasa mentioned Descriptive and Normative Ethos. Descriptive ethos describes the moral, customs, assumptions about good and bad and the actions that are allowed or not allowed. Normative ethos involves judgments about human behavior. ${ }^{(17)}$ Bertens $(2007: 15-17)$ argued that human dignity must be respected because it is a normative ethos and regarded as a dignified human beings. ${ }^{(18)}$

\section{The Malay as an Ethnic Group}

Sinar (2002:1) mentioned five ethnic Malay territorial states, such as, Indonesia, Malaysia, Singapore, Brunai Darussalam and Southern Thailand. ${ }^{(19)}$ Understanding Malay often leads to misunderstanding. This confusion occures because Malay can refer to language, ethnicity or nation. Specific residential areas include the Malays of Southern Thailand, East and West Malaysia, Singapore, Brunei, West Kalimantan, East Aceh, East Coast of North Sumatra, Riau, Jambi, and Palembang Coast.In the 18th century AD, the Dutch and the British considered all the inhabitants of the archipelago and the Malay Peninsula as a language understood by the name Malay Lingua Franca. Malay society is characterized by Malay's identity and Islam. Big changes occurredwhen the Malay kingdom fell and thiscreated inferiority among them and dependence on help from others.Sinar (ibid:40) further confirmed Malays should not be just looking for a scapegoat towardstheir bad luck which was caused by their own weaknesses.

Kinship system for older generations in BM shows a broader term which is in general devided into three, for example, Tuk Lung 'the eldest', Tuk Ngah 'the middle', and Tuk Cik 'the youngest'. Children would be given nick names which are based on their sequences of birth, for instance, sulung 'eldest', ongah 'the second', andak 'the third', uteh (lit. white) 'the fourth', ondo 'the fifth', andak 'the sixth', anjang 'the seventh', itam (lit. black) 'the eighth', and mayan or bongsu 'the ninth'. So the ideal number of children in this community are nine. When someone is called "Tengku Uteh", this does not mean that he/she has white skin but becausehe/she sits in the fifth rank of the birth; the same is also addressed to "Datuk Itam". All these nick names become the symbol of love. Batubara communities when welcoming their honourable guests always serve foods and drinks that are named as follows: lenggenang, kekaras, curd, piston plate, tumpur widow and peniaran.

\section{Results And Discussion}


Batubara is really rich of proverbs and some of them are only brought into discussion as mentioned in the followings: (i) kalau hendak menjadi orang, manfaatkan umur sebelum petang, pahit dan getir usah dipantang(lit. when (you) willing to be a man, use (your) age before dark, bitter and unpleasantness never be prohibited); (ii) kalau hendak menjadi manusia, ringankan tulang habiskan daya (lit. when (you) wish to be human being, light (your) bone spend (your) energy); (iii) kerja diperintahkan agama, sunah diperintahkan adat (lit. do work commanded by religion, the sunnite (Arabic assunah) governed by adat law); (iv) taat pada petuah, setia pada sumpah, mati pada janji, melarat pada budi (lit. obligation to the fortune, loyalty to the oath, die of promise, misery of moral); (v) adat mati jenguk-menjenguk, adat sakit datang-mendatangi (lit. the adat law of death means visiting each other, the adat law of sickness coming to each other); and (vi) berakit-rakit ke hulu berenang-renang ketepian, bersakit-sakit dahulu bersenang-senang kemudian (lit. rafting to the upper swimming to the river side, being previously suffered being happy afterwards). Those proverbs might surely express the working ethos and could have multi interpretations among the scholars and what is needed to know here is that such proverbs mean how to get and to reach the lofty ideals which should be achieved by working hard, by doing the utmost and by maintaining great efforts. All these are believed to be the potential requirements for Malays to become prosperous and to have self-control when they do their business in everyday life or when they walk on the universe.

The first proverb tells its readers to have good discipline by managing time but not to waste time. Readers are asked to spend time and work hard when they are still young. At young age many things can be done by them. They can concentrate to study, to do business, to run career, etc. Unluckily, when the petang 'dark' comes many things would be losing. The dark symbolizes the old age. The dark age is in the same analogy with bitter condition and unpleasantness; therefore, this age should be received as what it is. No need to worry or feel scared when this dark age comes because everybody must meet such condition. It is suggested that far before the age is approaching us, building good ethos by working hard and saving money is the only solution.

Motivation becomes the main characteristics of the second proverb. What this motivation wants from each Malay is that he/she must be successful in his/her life. Success is marked and appreciated when a Malay can become a teacher, lecturer, civil servant, entrepreneur, religious figure, member of parliament, etc. In this case he/she becomes "a person" which makes his/her family proud. After somebody becomes "a person" he/she is requested to light his/her bone; this indicates that lighting bone means giving power to everybody until the rest of his/her strength. To light bone and transfer energy a Malay should work hard and gets a fame in order he/she can help other people who live in miserable conditions. These conditions can only be erased when there are people who give their bones and transmit energies to the poor. Biologically bones are the symbols of powers; therefore, having bones mean to own working ethos in every day activities.

Responsibility dominates the fourth proverb. Every Malay should be faithful to wise words, fortune and once he/she says an oath, he/she must be loyal and places the oath in high place. Bad consequencies of the oath should be even received, for example, death or misery. When death occurs after a Malay carries out his/he promise, or when misery becomes the barriers after he/she fulfills his/her morals, all these are considered faithful and loyal to the wise words and oath. In short, a Malay is forced to keep his/her promise when he/she has promised to work hard and not to come late to the work place, not to waste time and not to come home earlier from work.

The fifth proverb consists of cooperation and team work. When somebody died, for example, all Malays were forced to come to say their condolences because the adat law in Malay is to visit the house of the dead to express sympathy and to feel what the dead's family members feel at that time.Meanwhile, in case of sickness Malays have duties to see the sick and tells him/her that disease comes from Allah and what He has decided should be accepted with open heart because what He has done always carries something hidden. No body knows the hidden except He himself. Seeing the sick by coming to the sick's house reflects a high attitude and this attitude becomes the real condition of cooperation.

The last proverb is complex. Rafting to the upper 'berakit-rakit ke hulu' contains hard work since it is not easy to achieve. Normally, swimming is carried out to the lower and this is easily done because a swimmer is helped by the power of water. However, swimming to the high position is difficult and requires big energy. After a swimmer reaches the upper he/she should come back to the river side and this is expressed by the phrase swimming to the river side 'berenang-renang ke tepian'. This phrase can also be interpreted as the time to fulfill energy after he/she swims to the upper. Inviting power to come back is not easy and requires time; this condition is symbolized as misery and in Malay proverb it is said as being previously suffered 'bersakit-sakit dahulu'. However, after miserable time is over, happy life will appear. The coming of the happy moment is clearly seen in the phrase being happy afterwards 'bersenang-senang kemudian'. In short, this last proverb gives advice to Malays to work deligently when they are young and to save money which will be used during the old age to have leisures.

\section{Conclusion and Suggestions}




\section{Conclusion}

From the results of this study it might be concluded that working ethos from some selected proverbs is found and the proverbs consist of advice, motivation, working hard, discipline, responsibility, and cooperation. Working ethos becomes Malay typical view consisting of customs, attitude, personality and character. The form of the language contained in the proverbs, phrases and rhymes are considered to be the guidelines and way of life. The proverbs are commonly addressed to parents, teens and children and have proved to build national character. The use and emphasis on the structure of the language in the proverbs which was expressed by the local speakers helped to determine the speaker's perception of the world and reality. Thus within the sentences, phrases and rhymes, the perceptions and thoughts about working ethos are proved to be available. In general the themes of the proverbs vary; however, specifically the themes relate to natural flora, fauna, nature, sea, water, and other natural objects. The role of language is very broad so as to foster the customs, values, norms and ideas of a nation. The underlying philosophy in creating such proverbs, phrases and rhymes is primarily influenced by the teachings of Islam. Since majority of Malays embrace Islam so there are some combinations of Islamic values and local ones.

\section{Suggestions}

1. The proverbs should be preserved in order to influence the ideology of ethnic Malay community especially Batubara's way of thinking, behaviour and act.

2. Local government needs to develop local curriculum related to local knowledge within the framework of the working ethos.

3. To face the increasing competition in this century some programmes must be relevant to the following: (a) orientation to action (action oriented), (b) orientation to quality (quality oriented), (c) orientation to goal (goal oriented), (d) orientation to the future (future oriented).

\section{Acknowledgement}

As part of my doctoral dissertation this article receives a lot of comments from my promotor and copromotors. I would personally be glad to thank all my informants during my field trip in Batubara Regency and I would also extend my deepest thanks to Muhammad Ali Pawiro for his careful proofreading, as well as his editing, of this article's earlier draft.

\section{References}

[1]. M. Mahathir, ww.topic.com/forum/world/malaysia.Retrieved in 6 October 2008

[2]. R. Sibarani, Antropolinguistik (Medan: Penerbit Pola, 2004).

[3]. T.L. Sinar, Adat Budaya Melayu Jati Diri dan Kepribadian(Medan: Forkala, 2005).

[4]. Www. Amazon.com/Variations-Value-Orientations-Florence-kluckhon/dp.

[5]. C. Geertz,The Interpretation of Cultures: Selected Essay (New York: No publisher, 1973) .

[6]. J.J. Gumperz, Language and Social Identity (Cambridge: CUP, 1982).

[7]. Www. Amazon.com/Variations-Value-Orientations-Florence-kluckhon/dp.

[8]. Koentjaraningrat, Sejarah Teori Antropologi I. (Jakarta: Rineka Cistra, 1981).

[9]. U. Pelly, Urbanisasi dan Adaptasi: Peranan Misi Budaya Minangkabau dan Mandailing(Jakarta: LP3ES, 1994).

[10]. C. Kramsch, Language and Culture (Oxford: Oxford University Press, 2001).

[11]. Www.Academia.edu/.../Budaya_Kerja_Masyarakat_Melayu_dalam_Menghadapi_Era_Globalisasi_di_Medan_Labuhan.

[12]. M.J. Collier, andM. Thomas,Cultural Identity: An interpretive Perspective. In W. Gundykunst \& Y. Kim (Eds), Theories of Intercultural Communication(Newburry Park, CA: Sage, 1988).

[13]. I.M. Swastika, Etos Kreatif Pemanfaatan Sumber Daya Kebudayaan dalam Pengembangan Ekonomi Kreatif (Bali: Udayana, 2010).

[14]. T. Effendy, Etos Kerja Dalam Acuan Budaya Melayu Riau, Pangkalan Kerinci: Makalah Mubes Lembaga Kerapatan Adat Melayu Kab. Pelalawan, (Riau: no publisher, 2003.

[15]. E. Rokhman, T. Mami and Zulkarnain, Alam Melayu: Sejumlah Gagasan Menjemput Keagungan(Riau: UNRI Press, 2007)..

[16]. A. Saidi, PerbandinganEtos Kerja Antara Pengrajin Santri dan Abangan: Studi Kasus di Kecamatan Tahunan Jepara, Laporan Penelitian (Jakarta: PMB-LIPI, 1997).

[17]. Dewan Bahasa dan Pustaka Kementerian Pelajaran Malaysia dan Kuala Lumpur, (1983).

[18]. K. Bertens,Etika. (Jakarta: Gramedia Pustaka Utama, 2007).

[19]. T.L. Sinar, and Wan Syaifuddin (Ed.), Kebudayaan Melayu Sumatera Timur(Medan: USU Press, 2002). 